\title{
IDENTIFYING RARE MONTANE MEADOW PARNASSIAN BUTTERFLY POPULATIONS ACROSS Grand TETON NATIONAL PARK, WYOMING
}

\begin{abstract}
$-2$

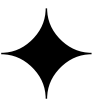

KIMBERLY E. SZCONDRONSKI $\uparrow$ DIANE M. DEBINSKI $\uparrow$ DEPARTMENT OF ECOLOGY, EVOLUTION AND ORGANISMAL BIOLOGY $\uparrow$ IOWA STATE UNIVERSITY $\uparrow$ AMES, IA
\end{abstract}

\begin{abstract}
$\uparrow \quad$ ABstract
The pristine, protected ecosystem of Grand Teton National Park (GRTE) is the ideal location to study the relationships between butterfly populations and the habitats on which these insects depend. Two montane meadow butterfly species, Parnassius clodius and Parnassius smintheus, were investigated in this study to identify patterns of habitat occupancy relating to variables across GRTE and into the surrounding territory of Bridger-Teton National Forest (BTNF). Population dynamics of $P$. clodius have been intensively studied by our research group over several consecutive years in one isolated population in Grand Teton National Park. However, little has been investigated regarding the Parnassian butterflies' population range across the GRTE ecosystem. For this study, presence-absence butterfly surveys were conducted across 45 meadow sites in preferred habitat during the Parnassius flight season (June - July 2013). We found that $P$. clodius occupied $80 \%$ of the meadows surveyed, which was far greater than was originally predicted. P. smintheus, the more rare Parnassian butterfly in the GRTE ecosystem, was only found at $9 \%$ of the meadows surveyed. Understanding population ranges and habitat limits of these butterfly populations will be useful for managers and scientists within GRTE, and will assist conservation efforts for other related Parnassian species that are threatened or endangered worldwide due to habitat loss and climate change.
\end{abstract}

\section{$\uparrow \quad$ INTRODUCTION}

The Clodius Parnassian (Parnassius clodius) and Rocky Mountain Parnassian (Parnassius smintheus) are two range-restricted high-elevation montane meadow butterfly species whose survival is highly dependent upon their surrounding environment. Montane meadow butterflies are sensitive to synchrony in plant-insect interactions relating to spring emergence timing, constrained to potentially shrinking habitats caused by tree encroachment (Roland et al. 2002, Roland and Matter 2007), and vulnerable to genetic isolation due to their small, isolated populations (Dirnbock et al. 2011). These two Parnassian species currently exist in several locations across Grand Teton National Park (GRTE) and the surrounding ecosystem. However, the related European Apollo Butterfly (Parnassius apollo) has been declining since the turn of the century due to long-term climatic changes, habitat succession, anthropogenic factors, and intrapopulation factors that include genetic erosion and behavioral changes in small demes (Nakonieczny et al. 2007).

Although $P$. clodius and $P$. smintheus are not currently threatened species, recent population fluctuations determined by mark-recapture studies performed by the Debinski lab from 1998 - 2000 (Auckland et al. 2004) and from 2009 - 2012 (Sherwood and Debinski, unpublished data) on one population of $P$. clodius in GRTE indicate the need for additional monitoring. Mark-recapture studies were conducted on what is considered to be one of the largest populations of $P$. clodius in GRTE along Pilgrim Creek Road (Auckland et al. 2004) to assess population parameters including sex ratio, population 
size, percentage of mated females, and emergence dates for males and females. However, there is limited information about the general population range of this butterfly genus across GRTE and it would be valuable to know how the Pilgrim Creek population compares to other populations within the ecosystem.

To determine where current populations of Parnassian exist in the park and surrounding ecosystem, presence-absence butterfly surveys were conducted for this study in potentially suitable habitat for $P$. clodius and $P$. smintheus in meadows across GRTE and into Bridger-Teton National Forest (BTNF) territory. In addition, potentially suitable habitats of $P$. clodius and $P$. smintheus were analyzed in the GRTE and BTNF study sites by collecting vegetation and nectar data to identify habitat requirements for these rare species. The results of this research will allow us to 1) estimate the current distribution patterns for each of the two species, 2) determine the fine-scale differences in habitat requirements between the species, and 3) develop a more rigorous model of habitat suitability for each species.

\section{$\uparrow \quad$ METHODS}

\section{Study area}

The butterfly and plant communities of GRTE, located within the large-scale protected ecosystem of the Greater Yellowstone Ecosystem (GYE), have been studied intensely by our lab over the last two decades. From 1997 to 2007, Debinski and colleagues collected long-term data on plant and butterfly distributions across 55 montane meadows in GYE along a hydrological gradient ranging from hydric to xeric meadows (Debinski et al. 2006, Debinski et al. 2010, Debinski et al. 2013). Parnassian butterflies' habitat preferences as determined by the long-term plant and butterfly surveys (Debinski et al. 2006, Debinski et al. 2010, Debinski et al. 2013), along with GIS vegetation data layers provided by the 2002-2005 Grand Teton National Park Vegetation Mapping Project (Cogan et al. 2005) were used to locate potentially suitable Parnassian habitat in the GYE ecosystem. GRTE includes a wide variety of habitat types encompassing both hydrological and elevation gradients. Based on the butterflies' known habitat preferences, meadow sites for this study were restricted to montane mesic forb herbaceous vegetation, montane xeric forb herbaceous vegetation, and meadows with low sagebrush (Artemisia arbuscula) or tall sagebrush (Artemisia tridentata) vegetation cover.

\section{Field surveys}

Presence-absence butterfly surveys were performed for $P$. clodius and $P$. smintheus across 45 meadow sites of the butterflies' preferred habitat requirements in GRTE and BTNF in the summer of 2013. To account for imperfect detection, presenceabsence surveys were conducted twice at each site throughout the butterflies' flight season (MacKenzie et al. 2002) with two independent observers searching for the butterflies for 30 minutes (MacKenzie et al. 2006) for a total of four surveys per site. If the butterfly species occupied the meadow in at least one out of the four butterfly surveys, then the butterfly was considered present at that meadow site. Butterfly surveys were only performed during optimal butterfly survey conditions (mid-June to mid-July at times between 10:00 and 17:00 hours when the temperature was above $21^{\circ} \mathrm{C}$ and wind was $<16 \mathrm{~km} / \mathrm{h}$ ).

\section{$\uparrow \quad$ RESUlTS}

As seen in Appendix 1, P. clodius was present at 36 out of the 45 meadow sites surveyed and $P$. smintheus was located at three out of the 45 meadow sites surveyed. The two Parnassian species only occupied the same meadow site once throughout the study and six of the study sites were unoccupied by both species. Of the sites surveyed for this study, $P$. clodius was found across a wide range of elevations from 2,006 meters to 2,503 meters and $P$. smintheus occurred at a more restricted range of 2,043 meters to 2,099 meters. Figure 1 shows a map of the study area of GRTE and BTNF displaying the population range of the more common Parnassian butterfly across the GYE ecosystem, $P$. clodius.

\section{$\uparrow \quad$ DISCUSSION}

This research indicates that $P$. smintheus is considered to be the more rare Parnassian species in GRTE, however this trend does not hold true across their habitat range in the entire GYE ecosystem. Based on previous butterfly and bird surveys conducted by the Debinski Lab, P. smintheus was more abundant in the northern region of the GYE ecosystem in Gallatin National Forest (Debinski et al. 1999, Debinski et al. 2006, Debinski et al. 2010). Of the meadow sites with preferred Parnassian habitat requirements, $P$. clodius occupied a surprisingly high percentage of the meadows, far exceeding our prior predictions of their population range in GRTE. While it is encouraging in the context of long-term viability that $P$. clodius was found at more sites than was 


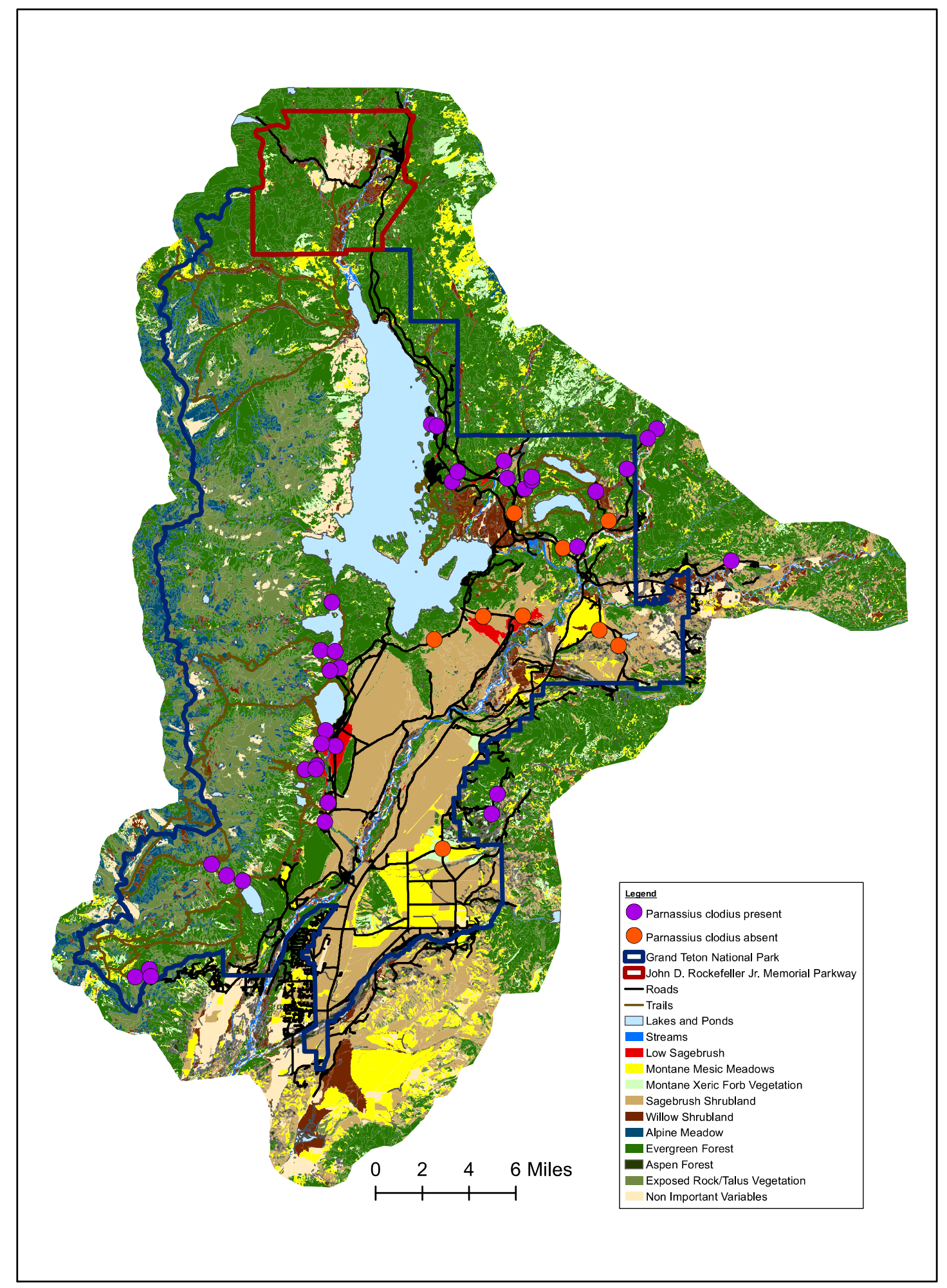

Figure 1. Vegetation map of Grand Teton National Park displaying occupancy of Parnassius clodius butterfly in meadow study sites surveyed from mid June - mid July 2013. 
originally predicted, it is important to also consider the total number of butterflies recorded at each study site summed across the four surveys. The majority of meadows occupied by $P$. clodius had an overall low abundance: 22 out of the 36 meadows contained less than 8 individuals. The remaining 13 sites had higher abundance, ranging from 14 to 35 total individuals recorded throughout the study. Additional markrecaptured studies would need to be performed at these sites to obtain a better estimate of the population sizes before any conclusions could be made on the status of these populations.

Occupancy modeling analysis in program PRESENCE (Hines and MacKenzie 2006) is currently being conducted using these butterfly presenceabsence data to estimate detection probabilities ( $\mathrm{p}$ ) and the probability of a site being occupied $(\psi)$ for both species across all of the meadow sites. Additionally, vegetation data for each meadow site were collected and vegetation analysis is underway to determine what habitat variables influence the occupancy of these montane butterflies.

\section{$\uparrow$ ACKNOWLEDGEMENTS}

Funding received from the Center for Global and Regional Environmental Research and the Iowa State University Department of Ecology, Evolutionary, and Organismal Biology supported this research. Thanks to Kathryn Mellander, GRTE GIS Specialist, for providing the GIS GRTE vegetation layers and to the 2002-2005 Grand Teton National Park Vegetation Mapping Project for making it possible to locate potentially suitable butterfly habitat. Our greatest appreciation goes to Jill Sherwood and Toni Proescholdt for assisting on data collection in Grand Teton National Park.

\section{$\uparrow \quad$ LITERATURE CITED}

Auckland, J. N., D. M. Debinski, and W. R. Clark. 2004. Survival, movement, and resource use of the butterfly Parnassius clodius. Ecological Entomology 29(2): 139-149.

Cogan, D., K. Varga, G. Kittel, K. McCloskey, D. Abendroth, J. Gremer, and C. Bolen. 2005. Grand Teton National Park 2002-2005 Vegetation Mapping Project Final Report. U.S. Dept. of the Interior, Bureau of Reclamation.

$<$ http://www1.usgs.gov/vip/grte/grterpt.pdf>
Debinski, D. M., J. C. Caruthers, D. Cook, J. Crowley, and H. Wickham. 2013. Gradient-based habitat affinities predict species vulnerability to drought. Ecology 94(5): 1036-1045.

Debinski, D. M., K. Kindscher, and M. E. Jakubauskas. 1999. A remote sensing and GIS-based model of habitats and biodiversity in the Greater Yellowstone Ecosystem. International Journal of Remote Sensing 20(17): 3281-3291.

Debinski, D. M., R. E. VanNimwegen, and M. E. Jakubauskas. 2006. Quantifying relationships between bird and butterfly community shifts and environmental change. Ecological Applications 16(1): 380393.

Debinski, D. M., H. Wickham, K. Kindscher, J. C. Caruthers, and M. Germino. 2010. Montane meadow change during drought varies with background hydrologic regime and plant functional group. Ecology 91(6): 1672-1681.

Dirnböck, T., F. Essl, and W. Rabitsch. 2011. Disproportional risk for habitat loss of highaltitude endemic species under climate change. Global Change Biology 17(2): 990996.

Hines, J. E., and D. I. MacKenzie. 2004. PRESENCE version 2.0. U.S. Geological Survey, Patuxent Wildlife Research Center, Laurel, MD.

MacKenzie, D. I. 2006. Modeling the probability of resource use: The effect of, and dealing with, detecting a species imperfectly. Journal of Wildlife Management 70(2): 367-374.

MacKenzie, D. I., J. D. Nichols, G. B. Lachman, S. Droege, J. A. Royle, and C. A. Langtimm. 2002. Estimating site occupancy rates when detection probabilities are less than one. Ecology 83(8): 2248-2255.

Nakonieczny, M., A. Kedziorski, and K. Michalczyk. 2007. Apollo butterfly (Parnassius apollo L.) in Europe: Its history, decline and perspectives of conservation. Functional Ecosystems and Communities 1(1): 56-79.

Roland, J, N. Keyghobadi, and S. Fownes. 2000. Alpine Parnassius butterfly dispersal: Effects of landscape and population size. Ecology 81(6): 1642-1653.

Roland, J., and S. F. Matter. 2007. Encroaching forests decouple alpine butterfly population dynamics. Proceedings of the National Academy of Sciences 104(34): 1370213704. 
Appendix 1: UTM (Universal Transverse Mercator) coordinates of the Grand Teton National Park and Bridger-Teton National Forest study sites (UTM NAD 1983 Zone 12N) with presence-absence data of butterflies Parnassius clodius and Parnassius smintheus for each meadow site collected from mid June - mid July 2013.

\begin{tabular}{|c|c|c|c|}
\hline Meadow Site & UTM Northing & UTM Easting & Parnassian Presence-Absence \\
\hline Aimee's Meadow & 533942 & 4861337 & P. clodius present \\
\hline AMK Ranch & 528713 & 4865045 & P. clodius present \\
\hline AMK Road & 529077 & 4864934 & P. clodius present \\
\hline Antelope Flats & 529470 & 4835784 & Both species absent \\
\hline Bearpaw Lake Intersection & 521838 & 4852775 & P. clodius present \\
\hline Bearpaw Lake Trail & 522079 & 4849388 & P. clodius present \\
\hline Buffalo Fork & 549358 & 4855639 & P. clodius present \\
\hline Christian Pond & 534432 & 4858912 & Both species absent \\
\hline Climbers Ranch & 521577 & 4838973 & Both species present \\
\hline Cow Lake 1 & 535004 & 4851840 & P. smintheus present \\
\hline Cow Lake 2 & 532269 & 4851812 & P. smintheus present \\
\hline Cygnet Pond & 530146 & 4861081 & P. clodius present \\
\hline Death Canyon Phelps Lake Junction & 515719 & 4833590 & P. clodius present \\
\hline Death Canyon Ranger Cabin & 513571 & 4834713 & P. clodius present \\
\hline Death Canyon Trail & 514608 & 4833957 & P. clodius present \\
\hline Dump Road & 530523 & 4861790 & P. clodius present \\
\hline Elk Ranch 1 & 540261 & 4850850 & Both species absent \\
\hline Elk Ranch 2 & 541592 & 4849795 & P. smintheus present \\
\hline Grand View 1 & 535627 & 4861193 & P. clodius present \\
\hline Grand View 2 & 535609 & 4861415 & P. clodius present \\
\hline Grand View Parking & 535142 & 4860599 & P. clodius present \\
\hline Hidden Falls Trail & 521439 & 4843954 & P. clodius present \\
\hline Lozier Hill Meadow & 538775 & 4856609 & P. clodius present \\
\hline Lozier Hill Road & 537747 & 4856522 & Both species absent \\
\hline Lupine Meadow & 521129 & 4843032 & P. clodius present \\
\hline Mt. Moran Turnout & 528887 & 4850207 & Both species absent \\
\hline North Jenny Lake & 522388 & 4848251 & P. clodius present \\
\hline Paintbrush Canyon Trail & 521072 & 4849468 & P. clodius present \\
\hline Pilgrim Creek & 533718 & 4862533 & P. clodius present \\
\hline Rendezvous Mountain 1 & 508298 & 4826970 & P. clodius present \\
\hline Rendezvous Mountain 2 & 509291 & 4827468 & P. clodius present \\
\hline Rendezvous Mountain 3 & 509376 & 4827000 & P. clodius present \\
\hline Shadow Mountain Hairpin & 532852 & 4838189 & P. clodius present \\
\hline
\end{tabular}




\begin{tabular}{llll} 
Sound of Music & 533257 & 4839554 & P. clodius present \\
String Lake Parking & 521728 & 4848059 & P. clodius present \\
Surprise Lake Meadow & 520001 & 4841263 & P. clodius present \\
\hline Surprise Lake Trail 1 & 520818 & 4841498 & P. clodius present \\
Surprise Lake Trail 2 & 520745 & 4841270 & P. clodius present \\
Taggart Lake Trailhead & 521361 & 4837657 & P. clodius present \\
Timbered Island & 522115 & 4842890 & P. clodius present \\
Two Ocean Lake Road 1 & 540926 & 4858405 & Both species absent \\
Two Ocean Lake Road 2 & 540030 & 4860396 & P. clodius present \\
Wilderness Road 1 & 544237 & 4864715 & P. clodius present \\
Wilderness Road 2 & 543598 & 4864076 & P. clodius present \\
Wilderness Road 3 & 542182 & 4861987 & P. clodius present
\end{tabular}

